\title{
ЭВОЛЮЦИЯ КОНЦЕПТА «СЧАСТЬЕ» В РУССКОМ ЯЗЫКЕ
}

\section{EVOLUTION OF «HAPPINESS» CONCEPT IN RUSSIAN LANGUAGE}

\section{U. Idzibagandova}

Summary: The article deals with the terms «Concept» and «Happiness». The author analyses various interpretations of «Happiness» concept used by domestic scientists. The process of the concept changing in the historical, cultural and sociological aspects is proved. The connection of the lexical and etymological meanings is given. Factors and conditions affecting the evolution of the concept of «Happiness» are distinguished.

Keywords: concept, concept «Happiness,» evolution of concept, the language unit.

\author{
Идзибагандова Уздият Исмаиловна \\ Аспирант, Московский государственный психолого- \\ педагогический университет, г. Москва \\ uzdiyat@bk.ru
}

Аннотация: (татья посвящена исследованию понятия «Концепт» и концепта «(частье». Автором дается подробный анализ существующих трактовок концепта «Счастье», используемых отечественными учеными. В работе обосновывается процесс изменения концепта в историческом, культурном и социологическом аспектах, доказана связь лексического значения слова с этимологическим. Выделяются факторы и условия, влияющие на эволюцию концепта «(частье».

Ключевые слова: концепт, концепт «(частье», эволюция концепта, языковая единица.

стей общества и отражение этого процесса на индивиде, расширение культурных связей народов, развитие международных отношений легло в основу эволюции концепта и, в частности, концепта «Счастье».

От века к веку, от народа к народу, от одного социума к другому прослеживается эволюция языка и его концептов. Термин «concept» в Европе используют как синоним слову «понятие», так как в латинском языке слово «conceptus» переводится как «понятие». Однако в латинском языке также есть слово conceptum, что означает «зерно», «зародыш». То есть это своеобразный росток смысла, первообраз понятий. Поэтому концепт является не понятием, а сущностью понятия, смыслом, который не обрел формы.

Анализ того, как происходило изменение концепта в историческом аспекте эволюции языка, как повлияло развитие социума и изменения ценностей в развитии индивида и общества в целом, систематизация факторов и условий, влияющих на эту эволюцию, является как задачей нашего исследования, так и средством изучения.

Первым российским учёным, употребившим данное понятие, был С.А. Аскольдов-Алексеев (1928 г). Он искал сущность понятия в общем представлении, ставя вопрос в ценности знания.

Д.С. Лихачёв понимал концепт как когнитивный и психологический заместитель понятия в индивидуальном и коллективном сознании людей, говорящих на одном языке: «Концепт есть мыслительное образование, которое замещает нам в процессе мысли неопределенное множество предметов одного и того же рода» [10: 4]. По мнению учёного, концепт - это не то, что возникает из значения слова, а то, что является слиянием словар- 
ного определения слова с личным и народным опытом носителей языка. Чем богаче опыт человека, тем богаче потенция концепта.

Ю.С. Степанов относил концепт к «коллективному наследию в сознании народа, его духовной культуре, культуре духовной жизни народа» [14: 157]. Таким образом, концепт можно определить как «национальный образ (идея, символ), осложненный признаками индивидуального представления» [14: 16].

Анализируя сущность термина на основании лингвистического и культурного подходов к концепту, следует отметить, что рассматриваемое понятие является основным, включающим в себя понятия общества о хорошем и плохом, о нравственности и безнравственности, истинном предназначении человека и т.д. [3: 17]. В своих научных трудах В.И. Карасик, исследуя разные подходы в изучении рассматриваемого нами концепта, как с лингвокогнитивной, так и лингвокультурной сторон, приходит к выводу, что данные подходы не исключают друг друга. [7: 117].

В данном исследовании В.И. Карасик подчеркивает, что концепт представляет собой первичное понятие и выражает объективное содержание слов, несущих смысл и передаваемых в различные сферы жизни и деятельности человека. Такие примеры находят свое воплощение в науке, искусстве и в обычной жизни [6: 123]. Определенный интерес представляет сопоставление С.Г. Воркачева, который сравнил сущность концепта с зонтом, поскольку аналогично зонту концепт «покрывает» разделы и предметные области множества гуманитарных направлений. Так, основными отраслями, в которых понятие концепта наиболее полно раскрывается, ученый считает когнитивную психологию, когнитивную лингвистику и лингвокультурологию [4: 42].

Свое определение концепта представила также В.Н. Телия. По ее мнению, концепт - это знание, которое приняло определенную форму, заняло свое место в структуре, рамке. Следовательно, концепт содержит в себе не только основные признаки объекта, но и те характеристики, которые в среде носителей языка наполняются знанием о сущности, приобретая национальную окраску, дополняя культурными ценностями. [16: 18].

Определенный интерес представляет собой характеристика, данная И.А. Стерниным. Он назвал концепт образованием, которое структурировано ментально. Исследователь считает это понятие основной единицей измерения процесса мышления. Концепт, согласно И.А. Стернину, представляет собой результат познавательной активности общества, индивида. Это полная информация о рассматриваемом предмете и событиях, а также понимание данной информации общественным созна- нием и отношением коллективного сознания к данному явлению или предмету. [15: 64].

В дальнейших исследованиях, например, В.В. Колесов, прослеживается обращение к генной памяти, которая является основой, прообразом концепта. [8: 24].

А.П. Бабушкин, как и большинство ученых, полагает, что концепт - единица сознания общества, хранящаяся в национальной памяти носителей языка, оформленная в виде слова [2: 65].

Согласно исследованиям Е.С. Кубряковой, есть еще одно понимание сущности концепта, который характеризуется как единица когнитивных и психических процессов в сознании человека, имея информационную структуру, отвечающую за получение знаний, умений и опыта каждого конкретного человека. Таким образом, Е.С. Кубрякова рассматривает концепт как единицу памяти, которая характеризуется как содержащая определенный ментальный лексический запас наличием концептуальной системы, хранящей представления человека об окружающем мире и явлениях, которые находят свое отражение в психике человека. Представляя собой знания, смысл, которыми руководствуется человек в мыслительных процессах и явлениях, концепт становится зеркальным отражением опыта, знания.

В работах А. Вежбицкой концепт характеризуется в качестве того совершенного, что есть в психическом и психологическом мире индивида. Согласно её трактовке, одному и тому же слову конкретного языка в сознании разных людей соответствуют разные концепты. Помимо этого, она выделяет «концепт-минимум» и «концепт-максимум». Под «концептом-минимумом» понимается частичное представление о смысле слова, оно присуще обычному носителю языка, которому определённая реалия знакома, но в то же время не важна в жизненной практике. При этом знание концепта-минимума не должно быть ниже некой границы, за пределами которой принято считать, что носитель языка указанным концептом не владеет. Концепт-максимум - это более полное понимание смысла слова, которое свойственно рядовому носителю языка [3: 205].

Обобщая основные определения сущности концепта, следует проследить тенденцию к пониманию концепта как единицы сознания, которая характеризует весь накопленный опыт индивида, его личные знания, которые приобрели определенную огранку под воздействием культурных, социальных и языковых факторов. Это словесное оформление понятий и представлений человека о явлениях, сущностях бытия и познания.

Среди отечественных лингвистов немало тех, кто занимался и занимается теоретическим исследованием термина «концепт» и типологией концептов, среди них А.П. Бабушкин, Н.Н. Болдырев, Н.В. Володин, В.И. Кара- 
сик, Г.Г. Слышкин, А.Д. Шмелев. В сферу их научных интересов входят разнообразные конкретные концепты.

В античные времена Счастье было связано с наличием разума. А в Греции понятие «счастье» очень схоже с современными представлениями мира о счастливом бытии, о наслаждении жизнью, о благосклонности судьбы и об удовлетворенности ее различными аспектами.

В христианстве под счастьем подразумевается умение жить в соответствии с моралью и нравственностью.

Таким образом, за два тысячелетия понимание счастья менялось от благоприятной судьбы до удовольствий. Когда счастье понимается как состояние человека, важно соответствовать моральным нормам. Когда же счастье осознаётся как удовольствие, нравственная составляющая отходит на второй план.

С развитием человечества Счастье стали понимать не как отдельный предмет, а как абстрактное имя.

Проанализируем, как в русском языке понимали «счастье» в досоветский период.

Согласно Далю, счастье - «1. Рок, судьба, часть и участь, доля. Такое наше счастье, что на мосту с чашкой. Всякому свое счастье; в чужое счастье не заедешь. 2. Случайность, желанная неожиданность, талант, удача, успех, «спорина в деле», не по расчёту. Кому счастье (кто счастлив) в игре, тому несчастье (mom несчастлив) в женитьбе. Кому счастье, кому ненастье. 3. Благоденствие, благополучие, земное блаженство, желанная, насущная жизнь, без горя, смут, тревоги; покой и довольство; вообще, все желанное, все то, что покоит и доволит человека, по убеждениям, вкусам и привычкам его. Счастье в нас, а не вокруг да около. Лады в семье, большое счастье! Даст Бог здоровья, даст и счастье.» [5: 620].

На основе данных определений можно выделить для лексемы «счастье» категориально-лексическую сему «судьба».

Это доминирующее значение указывает на связь лексического значения слова с этимологическим, которое, как было отмечено, объединяет счастье с участью, долей.

В словарях советского периода приводят практически одинаковые толкования слова «счастье».

Для примера обратимся к «Малому академическому словарю».

Счастье - «1. Состояние высшей удовлетворенности жизнью, чувство глубокого довольства и радости, испытываемое кем-л. Семейное счастье. Народное счастье. ॥ Внешнее проявление этого чувства. Самое полное счастье светится на лице его. Достоевский. Подросток. 2.
Успех, удача. Счастье в игре. Военное счастье. Тяжелый год - сломил меня недуг, Беда застигла, - счастье изменило, - И не щадит меня ни враг, ни друг, И даже ты не пощадила! Н. Некрасов. Тяжелый год... Хаджи-Мурат всегда верил в свое счастье. Затевая что-нибудь, он был вперед твердо уверен в удаче, - и все удавалось ему. Л. Толстой. Хаджи-Мурат. 3. в знач. сказ. Хорошо, удачно. [Фамусов:] Да! счастье, у кого есть этакий сынок! Грибоедов. Горе от ума. - Ну вот мы и дома, Андрейка! Какое счастье, что мы уже вместе. Николаева, Жатва. || (в сочетании с мест.: "мое“, "твое“, „его“, „ваше“). 4.Участь, доля, судьба. (простореч.) Всякому свое счастье. Поговорка» [11: 320].

Категориально-лексическая сема в основном значении, которая является общей для всех советских толковых словарей, может быть охарактеризована словом «состояние». В этот смысл вкладывается состояние как в материальном, так и в психологическом, культурном аспектах и явлений общества и индивида.

В постсоветский период в «Толковом словаре с включением сведений о происхождении слов» под редакцией Н.Ю. Шведовой выделяется более современная сема у слова «счастье».

Счастье - «1. Чувство и состояние полного, высшего удовлетворения. Состояние радости и комфорта, состояние покоя и полета. С. созидания. Стремление к счастью. Семейное счастье - это когда тебя понимают (афоризм). Личностное счастье - понимать других и быть понятым коллективом. Успех, удача. Удача и ее принятие и ощущение сопоставимы с отсутствием противоположных явлений Не бывать бы счастью, да несчастье помогло. То есть удача - это своего рода отсутствие неудачи и дискомфорта. 3. Повезло, что такое случилось (разг.) Замерз, с. еще, что не промок. Забыл ключи: с., что кто-то был дома» [12: 963].

В данной семной структуре можно выделить категориально-лексическую сему «успех» и дифференциальную сему причины - «достижение чего-либо».

Опираясь на лексикографический анализ толковых словарей разных исторических периодов, кроме ядерной семы «состояние довольства, удовлетворения», можно выделить ряд интегральных сем, которые являются общими для всех промежутков: радость, успех, удача, судьба. Отсутствие диаметрально противоположных эмоций и состояний также показывают существование счастья. В совокупности все вышеуказанные явления образуют концептуальные слои «счастья».

В рамках настоящей статьи теоретический анализ понятия концепта и концепта счастья позволил проследить эволюцию исследуемого нами понятия. Изучение основных определений сущности концепта, позволило проследить тенденцию к пониманию концепта как едини- 
цы сознания, которая характеризует весь накопленный опыт индивида, его личные знания, которые приобрели определенную огранку под воздействием культурных, социальных и языковых факторов.

Изменение мира, жизни и деятельности человека как ячейки общества, изменение ценностей общества и отражение этого процесса на индивиде, расширение культурных связей народов, развитие международных отношений легло в основу эволюции концепта и, в частности, концепта «Счастье». Счастье стало целью жизни человека и объектом достижения всего человечества. Сквозь года, от социума к индивиду, от одного социума к другому прослеживается эволюция языка и его концептов. Представленное исследование обозначило широту и многогранность рассматриваемой проблемы. Процессу эволюции русского языка способствовали различные факторы. Влияние этих факторов стало причиной изменения и концепта счастья.
Таким образом, являясь словесным оформлением понятий и представлений человека о явлениях, сущностях бытия и познания концепт счастья менялся с развитием бытия человека, многообразия изменяющихся явлений и методов познания.

В результате проведенного нами анализа концепта счастья, основанного на сопоставлении словарных дефиниций, можно проследить семантическую эволюцию концепта «счастье»: в древнейших семных структурах выделялась категориально-лексическая сема «доля», «участь»; в дальнейшем эта сема трансформировалась в «состояние», речь сегодняшних носителей языка зачастую предполагает сему «успех».

Сделанные нами выводы дают основание предполагать и дальнейшие изменения концепта «Счастье», подтверждая актуальность проводимого исследования и открывая новые перспективы его изучения с развитием мира, общества, ценностей.

\section{ЛИТЕРАТУРА}

1. Аскольдов С.А. Концепт и слово / Русская словесность. От теории словесности к структуре текста. Антология. - М., 1980.

2. Бабушкин А.П. Концепты разных типов в лексике и фразеологии и методика их выявления / А.П. Бабушкин // Методологические проблемы когнитивной лингвистики: сб. науч. тр. / под ред. И.А. Стернина. - Воронеж: Изд-во ВГУ, 2001. - С.52-57.

3. Вежбицкая А. Язык. Культура. Познание: пер. с англ. / А. Вежбицкая / отв. ред. М.А. Кронгауз, вступ. ст. Е.В. Падучевой. - М.: Русские словари, 1996. 416 c.

4. Воркачев С.Г. Лингвокультурология, языковая личность, концепт: становление антропоцентрической парадигмы в языкознании / С.Г. Воркачев // Филологические науки. - 2001. - №1. - С.64-72.

5. Даль В.И. Толковый словарь живого великорусского языка: В 4-х т. СПб, 1998.

6. Даль В.И. Пословицы русского народа: В 3-х т. Т.1. СПб, 1996.

7. Карасик В.И. Языковой круг: личность, концепты, дискурс / В.И. Карасик. - М.: Гнозис, 2004. - 390 с.

8. К КСКТ - Краткий словарь когнитивных терминов / под ред. Е.С. Кубряковой. - М.: Изд-во МГУ, 1996. - 248с

9. Колесов В.В. Русская ментальность в языке и тексте / В.В. Колесов. - СПб.: Петербургское востоковедение, 2006. - 624 с.

10. Кубрякова Е.С. Роль словообразования в формировании языковой картины мира / Е.С. Кубрякова // Роль человеческого фактора в языке: язык и картина мира. - М., 1988. - С. 141-172.

11. Лихачев Д.С. Концептосфера русского языка// Русская словесность -М, 1997.

12. Малый академический словарь / Ред.: А.П. Евгеньева, М., 1957-1960 (АН СССР, Ин-т рус. яз.; Под ред. А.П. Евгеньевой. — 2-е изд., испр. и доп.

13. Махмудова С.М. Языковая репрезентация аксиологической доминанты концепта 'Этика' ('Абыр') в национальной картине мира рутулов [Электронный ресурс] // Язык и текст. 2018. Том 5. № 2. С. 75-81. doi:10.17759/langt.2018050213

14. Ожегов С.И. Словарь русского языка: 70.000 слов/Под ред. Н.Ю. Шведовой.-М.: Русский язык, 1990

15. Пименова М.В. Методология концептуальных исследований / М.В. Пименова // Антология концептов. - Волгоград, 2005. - Т.1. - С. 15-20.

16. Степанов Ю.С. Константы: Словарь русской культуры. Опыт исследования / Ю.С. Степанов. - Москва : Школа «Языки русской культуры», 1997. - 990 с.

17. Стернин И.А. Методика исследования структуры концепта / И.А. Стернин // Методологические проблемы когнитивной лингвистики: сб. науч. тр. / под ред. И.А. Стернина. - Воронеж: Изд-во ВГУ, 2001. - С.58-65.

18. Телия В.Н. Метафоризация и ее роль В создании языковой картины мира / В.Н. Телия // Роль человеческого фактора в языке: Язык и картина мира. М., 1988. - C. 173-204.

19. Ушаков Д.Н. Толковый словарь русского языка: В 4-х т.М., 1996.

20. Три века русской поэзии / Сост. Н.В. Банников.- М.: Просвещение, 1986.

21. Фасмер М. Этимологический словарь русского языка: В 4-х т.М., 1986.

22. Шанский Н.М., Боброва Т.А. Школьный этимологический словарь русского языка: Происхождение слов. М., 2000. 